\title{
AIDS in children adds to Romania's troubles
}

\section{- Ceaucescu legacy of public health problems - Microtransfusions blamed for outbreak}

\section{Bucharest}

AN alarming outbreak of AIDS among young children in Romania appears to have spread through the practice of giving 'microtransfusions' of whole blood or plasma to malnourished or sick children in order to help build up their strength. The practice is not used in the West.

Five hundred and fifty Romanian children have been identified who are infected with HIV, most of them under three years of age. More than one child in three was found to be infected in tests conducted in hospitals and orphanages in the districts of Bucharest, Giurgiu and the Black Sea port of Constanta. But tests of 280 children in the central and western Romanian cities of Sibiu and Timisoara revealed no infection.

All the children infected before the age of three are likely to die of AIDS-related infections like lymphoma or tuberculosis within two years, according to Ludovic Paun of the Romanian national HIV reference centre. The children are thought to have been infected since mid-1989; Romania had reported to the World Health Organization (WHO) 74 cases of AIDS up to September 1989 , including 50 cases in children.

Whether the disease was spread in other ways is still unknown. Young children may also have been infected through the use of unsterilized needles and syringes for vaccinations or vitamin $\mathrm{D}$ injections both are commonly given to children under three years of age in Romania. Sterile equipment was not available in sufficient quantities in Romania and the hard currency was not provided by the government to purchase it.

The WHO sent a team to Romania this week to advise the government on the establishment of a national AIDS programme. David Heymann, an epidemiologist at WHO in Geneva said the new officials in the Ministry of Health were very interested in the programme and would be able to coordinate it capably.

The attitude of the current government towards AIDS stands in stark contrast to that of the Ceaucescu regime. The old regime hindered researchers in their efforts to screen for the HIV virus and prevented researchers from meeting to discuss the problem. Physicians had to use other diagnoses such as "septicaemia" and "unspecified infection" in order to bring the children to a central clinic in Bucharest for treatment.

The widespread use of microtransfusion was a result of the conditions caused by Ceaucescu's efforts to increase the population of Romania. His regime forbade both birth control and abortion for women who had not yet had five children or reached the age of 45 years. But in many families, there was not enough money to feed or clothe all the children properly and many children were abandoned.

When a child became ill or undernourished, parents often thought that the child would be better cared for in hospital, where, they believed, there would at least there would be warmth, food and medication, said Stiriu Brindusa, a medical resident in Bucharest. But often the doctors had few supplies, which led to the use of microtranfusion. The practice has now been stopped.

The Paris-based Medecins du Monde has helped deliver one million disposable syringes, 5,000 sets of reagents for the ELISA test for HIV, and other materials.

Heymann said that screening of all blood and blood donors (of whom 600,000 give blood annually in Romania) would cost millions of dollars. He emphasized that only by pooling the resources of all the aid organizations with government aid from other countries could the epidemic be brought under control in Romania. Several other East European countries have also asked WHO for help in evaluating their national AIDS programmes and will attend a meeting on 27 February to discuss their needs.

Brindusa, who spent much of the past year caring for children with AIDS, said that the turnabout in AIDS policy was for her the "second best effect of the revolution. Now we can say that the disease exists and do something about it." The best effect of the revolution, she said, is "That idiot [Ceaucescu] is dead."

Steven Dickman

\section{Correction: HERA}

THE headline of last week's article about the German and US particle accelerators (HERA and SSC) erred in representing the extra cost at Hamburg as $\$ 300$ million, which is the estimated extra cost of SSC. The text explains that an extra DM30 million may be spent on improvements to the injector, not the "magnets", at HERA. The article also said that there is "a certain minimum luminosity" below which colliders such as HERA yield no collisions; in reality, the collision rate increases with the intensity of each beam. Nature regrets these errors.

\section{Keeping them guessing}

\section{Paris}

THREE hundred scientists from 35 countries met at the Paris headquarters of the United Nations Educational, Scientific and Cultural Organisation (UNESCO) at the end of last month to discuss the prospects for international cooperation on the human genome project. Enthusiasm for the project was there - but not agreement on who should do the work, who should pay for it and, above all, "when to go big", as the European Commission's director-general of science, research and development, Paolo Fasella, put it.

To the surprise and relief of many delegates, James D. Watson, director of the US National Institutes of Health Center for Genome Research, said that an all-out drive for automatic end-to-end sequencing of the human genome would not begin for five years. Eric Barnard, of the British Medical Research Council Molecular Neurobiology Unit at Cambridge, suggested that Europe could wait longer to join the effort to sequence the genome from end to end. But Norton Zinder, of Rockefeller University, expects a substantial contribution to the work from countries other than the United States, which says it will "do and pay for no more than half the work".

Both A. A. Bayev of the Soviet Academy of Sciences and Kenichi Matsubara, Japanese vice-president of the Human Genome Organisation (HUGO), left little doubt for US scientists that, if they wanted to 'go big' immediately, they would probably be alone. According to Bayev, the Soviet Union is handicapped by its lack of hardware. "I hope for a not brilliant but not bad future", he said, "We do not have new generation computers, but we have very very good mathematicians."

Japanese scientists want to support HUGO, the international body set up to coordinate human genome research, but need more time before they can win financial support from the government - despite the threats made by Watson in January that Japanese scientists could not expect to share US data if their government did not make a contribution in keeping with its economy.

Watson has since softened his position. He now suggests that scientists should be entitled to sit on their data. "I hope other countries will join in", he said. "The costs will come down. If we did sequence completely, which we won't, we'll have the fun of looking at the sequence before we release it." How long might participants keep the data to themselves? Six months was the estimate made by Zinder but there was a feeling that this was just another guess.

Peter Coles 